\title{
Women's Collective Action and Sustainable Water Management: Case of SEWA's Water Campaign in Gujarat, India
}

\author{
Smita Mishra Panda, \\ Institute of Rural Management (IRMA)
}

International Research Workshop on 'Gender and Collective Action' October 17-21, $2005 \cdot$ Chiang Mai, Thailand

The CGIAR Systemwide Program on Collective Action and Property Rights (CAPRi) is an initiative of the 15 centers that belong to the Consultative Group on International Agricultural Research. The initiative promotes comparative research on the role played by property rights and collective action institutions in shaping the efficiency, sustainability, and equity of natural resource systems. CAPRi's Secretariat is hosted by the International Food Policy Research Institute's (IFPRI) Environment and Production Technology Division (www.ifpri.org.

CAPRi Working Papers contain preliminary material and research results and are circulated prior to a full peer review in order to stimulate discussion and critical comment. It is expected that most Working Papers will eventually be published in some other form, and that their content may also be revised. http://dx.doi.org/10.2499/CAPRiWP61.

Copyright ( $\odot$ June 14, 2007 International Food Policy Research Institute. All rights reserved. Sections of this material may be reproduced for personal and not-for-profit use without the express written permission of but with acknowledgment to IFPRI. To reproduce the material contained herein for profit or commercial use requires express written permission. To obtain permission to reprint, contact the IFPRI Communications Division at ifpri-copyright@cgiar.org.

CGIAR Systemwide Program on Collective Action and Property Rights (CAPRi) C/O INTERNATIONAL FOOD POLICY RESEARCH INSTITUTE 


\begin{abstract}
This paper discusses the Self Employed Women's Association's (SEWA) Women, Water and Work Campaign which organizes women's collective action in Gujarat, India to sustain local water management. Some of the significant factors that have sustained women's collective action are the presence of strong grassroots institutions, the establishment of a technical cadre of women, the ability of women's groups to transcend social barriers and continuous dialoguing with the state. Women have benefited in terms of increased income, reduced drudgery, improvements in the livelihoods of their families, reduced migration of both women and men and increased participation in SEWA's other programs. The most important impact observed is the strengthening of women's collective agency and women's confidence to independently negotiate in the public domain in the water management sector, which was earlier occupied by men. Women's collective agency has catalyzed some gender-equitable change processes at the household level among SEWA leaders but the impacts are not yet widespread.
\end{abstract}

Keywords: Collective action, India, water management, gender relations 


\section{TABLE OF CONTENTS}

$\begin{array}{ll}\text { Introduction } & 1\end{array}$

$\begin{array}{ll}\text { Methodology } & 3\end{array}$

Self Employed Women's Association's (Sewa): Women, Water, and Work Campaign 4

Collective Action of Women - The Struggle and Success 14

Impact of Collective Action on Women $\quad 19$

$\begin{array}{ll}\text { Concluding Remarks } & 23\end{array}$

$\begin{array}{ll}\text { References } & 25\end{array}$ 


\title{
Women's Collective Action and Sustainable Water Management: Case of SEWA's Water Campaign in Gujarat, India
}

\author{
Smita Mishra Panda ${ }^{1}$
}

\section{INTRODUCTION}

There is growing body of literature drawing from various disciplines on collective action for natural resource management (Baland \& Platteau 1996; Wade 1998; Ostrom 1990; Reddy 2000; D'Silva and Pai 2003; Poteete and Ostrom 2004). The resources in question are primarily common pool resources such as pasturelands, community forests, degraded forest lands, village wastelands, swidden lands, watersheds, ponds and tanks. In India, there are several instances of people coming together at the community level to protect and develop land and forests or conserve and revive water sources. However, in such indigenous community-level institutions, women by and large have been accorded a secondary status with respect to their role in decision making and management of the resources, although in reality they may be active in different tasks related to the protection or conservation of the resource. Alternatively, there are several instances in India where women on their own have come together to protect natural resources, the most well known among them being the 'Chipko movement'. ${ }^{2}$ The potential of women's groups to contribute to natural resource management and its protection has been highlighted in various studies (Shiva 1988; Agarwal 2000; Mishra-Panda 1996; Chen 1993; Sarin et al. 1999). Consequently, several programs (both state and non-state) have facilitated the formation of either mixed-sex groups or women's groups for the purpose of managing natural resources. The state

\footnotetext{
${ }^{1}$ Dr. Smita Mishra Panda, Associate Professor, Institute of Rural Management (IRMA), PO Box 60, Anand, Gujarat, 388001 India.

${ }^{2}$ A movement in which women embraced the trees in order to save them from felling by outside contractors in the hills of Northern India (Uttar Pradesh).
} 
has thus provided an institutional space for collective action to formally operate at the ground level. The arrangements can range from those that simply attempt to increase users' involvement in management as a supplement to state management (participatory or co-management) to those that transfer full responsibility and control over resources to organized users (Meinzen-Dick et al. 2002).

Collective action by local community groups depends on some important factors, including institutional arrangements, clear incentives (short and long term), social capital (cohesiveness and social structure of the community), property rights, leadership, assumed gender roles and responsibilities, a sense of ownership and transparent mechanisms for the sharing of benefits. In the wake of several community institutions for natural resource management, Agarwal (2000) has raised an important question relating to equity and efficiency of collective action by noting that most of the literature on collective action and natural resource conservation has neglected gender as a concern by considering households and communities to be un-gendered units. As a consequence, there could be a distortion of theory, empirical analysis and policy on collective action in three significant ways: (a) inappropriate assessment of community resource management institutions from equity and efficiency points of view which might suggest success even though gender inequality exists; (b) failure to take advantage of significant opportunities to promote effective collective action through women's efforts, which may be distinct from men's with respect to cooperative functioning and; (c) failure to take into consideration distinct ways in which women and men organize for natural resource management.

This paper examines the efforts of the Self Employed Women's Association (SEWA) to mobilize women for its Women, Work and Water Campaign in Gujarat in western India. Through the campaign, SEWA works with women's groups to provide water primarily for 
domestic use and to some extent for irrigation, to rural communities. It is worthwhile to explore SEWA's water campaign, as it represents a case where the factors for the success of women's collective action as mentioned in the above paragraph are clearly visible. The analysis includes the intervention process of the water campaign, the different activities initiated through collective action by women, the impacts of the campaign on livelihoods and gender relations, as well as policy implications. SEWA's case is most appropriate and significant to study collective action where women have organized themselves into collectives in a unique manner for cooperative functioning in a society that is feudal and patriarchal.

\section{METHODOLOGY}

Since its inception in 1995, SEWA's Women, Water and Work Campaign has been widely written about by scholars and journalists. SEWA has also documented the program in both English and Gujarati. The reports, by and large, describe the nature and functioning of the program and present facts and figures covering its spread and progress. Apart from a review of published reports and documents, the study at hand looks at the water campaign from the perspective of women's collective action in sustaining water management activities initiated by SEWA. Three sites (in three different districts - Mehesana, Surendranagar and Sabarkantha in Gujarat) were identified for the study, taking into consideration that the activities initiated by the women's collectives in collaboration with SEWA were representative of the program. A primary survey was conducted in six villages where the campaign runs. The primary survey included focus group discussions (FGDs) with community groups (mostly women members of SEWA) and key respondent interviews (structured and unstructured) across all stakeholders such as community representatives, government officials and SEWA personnel, including women 
leaders (ageyvans) at the village level. In all, 13 FGDs were held, six with women-only collectives (averaging 15 women per collective), and seven with mixed-sex collectives. The study was conducted in phases in 2005. Based on emerging issues, FGDs were designed and modified suitably. Several interviews were held with the water campaign coordinator based in Ahmedabad so as to understand SEWA's collaboration with the state and the policies adopted by SEWA with respect to the campaign across the districts of Gujarat. The men interviewed were those who were supportive of the program and helped in coordinating the program with women leaders at the village level.

\section{SELF EMPLOYED WOMEN'S ASSOCIATION'S (SEWA): WOMEN, WATER, AND WORK CAMPAIGN}

Established in 1972, SEWA is the largest self employed women's trade union in India. ${ }^{3}$ It is a membership- based organization with approximately 800,000 members throughout the country, of whom more than 500,000 are based in the state of Gujarat (Figure 1). The members are all poor women belonging to the informal sector, two-thirds of whom live in rural areas. SEWA strongly believes that the basis of development and progress is through organization. It works with the two-fold objective of providing full employment to its members and empowering them to be self-reliant. SEWA combines four specific strategies: organizing women, since individual women in India have no voice; building the capacity of women to become owners and managers, not just producers and laborers; encouraging capital formation at the household, group and community levels; and increasing social security to enhance women's well-being and

\footnotetext{
${ }^{3}$ Although SEWA is a trade union, it functions as an NGO. The Women, Water and Work Campaign, also referred to as the Millennium Campaign, won an award in the Best Practice category in Kyoto Water Forum 3 (2003).
} 
productivity in order to reduce the impacts of crisis on fragile household economies (SEWA, 2003).

Figure 1 - Location of Gujarat and the SEWA's Water Campaign Areas

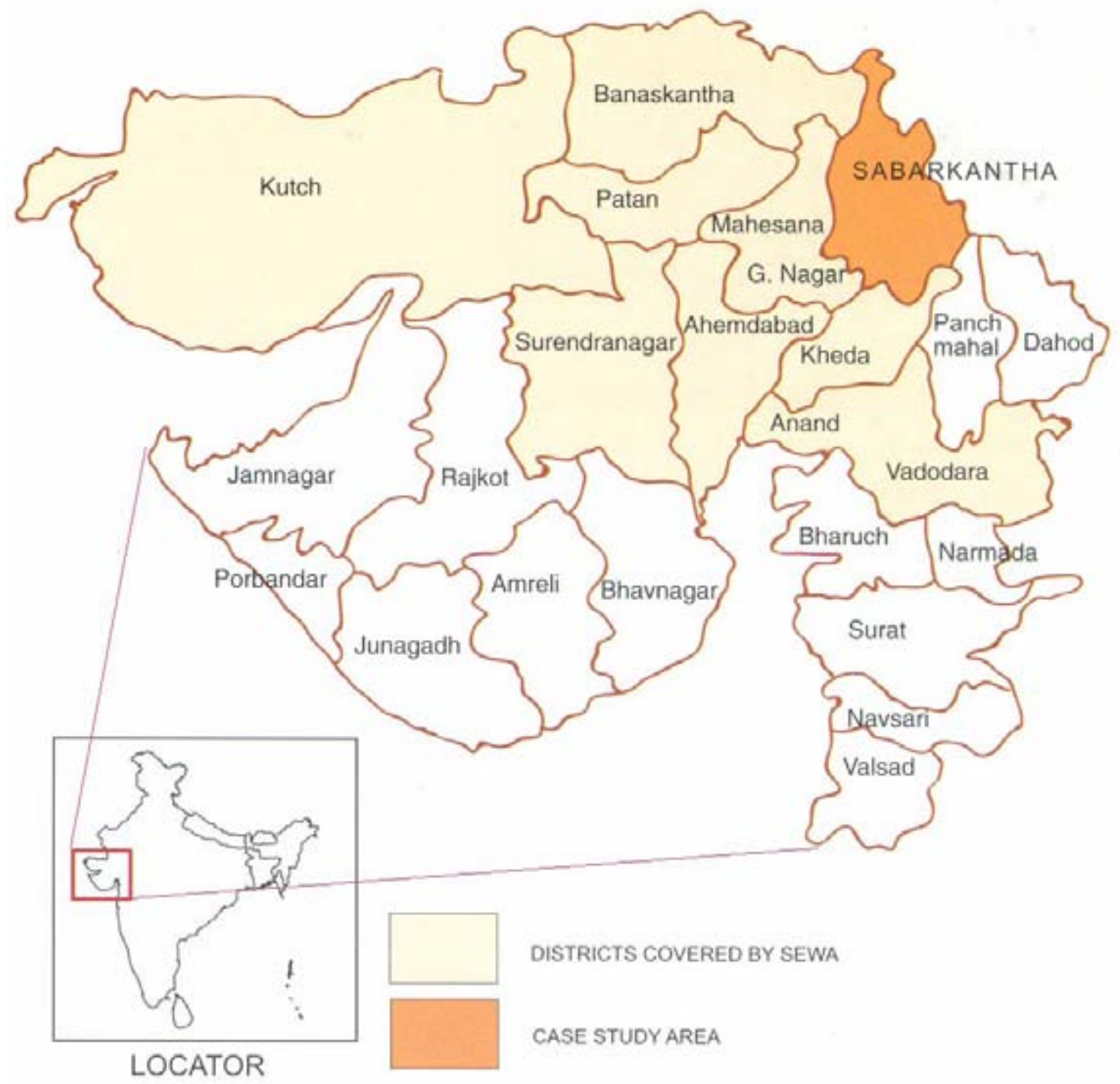

Note: The areas marked in orange are covered by the hand-pump repair and maintenance program.

SEWA's experience is that women, water and work are integrated and their combination can effectively fight poverty, as women use water for both domestic and economic purposes (e.g. as artisans, producers, laborers and traders) (Nanavathy 2000). The need to have access to water was raised by members (across caste and class) in most grassroots level meetings 
organized by SEWA on development programs such as income generation, health, education or savings for credit and thrift.

"It takes so long to fetch water, where is the time to undertake income-generating activities? Irrigation is important but first we want drinking water for ourselves and for our cattle. If we get water closer to our homes, we can undertake animal husbandry, craft work and attend SEWA meetings. Fetching water from far even during pregnancy tells on our health. How can tired and weak women undertake income-generation activities?" - A SEWA member emphasizing that drinking water is her first demand.

"During summer, we hardly slept as we had to collect our drinking water from small 'virdas' (shallow pits in the pond) each of which would take an hour to fill with a pot of salty water. This would go on for the entire night. During the day the water would evaporate. There would be always quarrels over water" - Woman of Datrana village

The Women, Water and Work Campaign began in 1995 in Gujarat. Although SEWA has been involved in water management issues in Gujarat since the mid-1980s, its scale of activities has increased to a great extent with the water campaign, as has its membership. It may be mentioned that in 1986, the Gujarat Water Supply and Sanitation Board (GWSSB) invited SEWA to use its grassroots base to strengthen village-level water committees (pani samitis) so that the local people could take over the failing water supply systems. SEWA agreed to take on the task as it realized that water was a critical issue affecting the productivity and the quality of lives of its women members at the village level. Through regular meetings with women and men in the villages, SEWA was able to identify two urgent needs- the need to find non-water based economic work and the need to conserve water, revive traditional sources like surface wells and ponds, and create alternative water sources like rainwater harvesting. Many activities were initiated by SEWA through women's groups to maintain and augment water supply systems (both modern and indigenous). Although the results of this early partnership between SEWA and the GWSSB were mixed, it nevertheless provided a foundation, for SEWA's Millennium Water 
Campaign (Capoor 2003). The most important outcome of the partnership was the trust that

SEWA was able to establish in relation to the government. Subsequently, as part of the campaign, the GWSSB has facilitated building the capacities of women for hand pump and pipeline maintenance. Further, the government collaborated with SEWA for maintenance of water infrastructure in many districts of Gujarat.

\section{THE CAMPAIGN}

SEWA's Millennium Water Campaign is a mobilization and development intervention, spread across 11 districts covering more than 200,000 women in 500 villages of Gujarat (SEWA 2003; Ahmed 2002, 2005). The organization believes in decentralized local water management that has the potential to address location-specific situations in rural Gujarat. The campaign activities can be broadly classified as follows:

- $\quad$ raising women's awareness and also that of their families regarding water related issues such as saving water and its availability, hygiene, functioning of the government apparatus and so on;

- establishing local water user groups (of mostly women leaders) called 'pani samitis' (water users) for the maintenance and management of community water sources;

- building the capacity of women through leadership and technical training (repair and maintenance of handpumps, operation and maintenance of piped water supply schemes, and monitoring of the performance of government water supply activities; and

- augmenting existing community water supply systems through construction of roof rainwater harvesting systems, upgrading and repair of traditional water sources, and micro-watershed development (Verhagen and Agarwal, 2004).

SEWA's decentralized water campaign includes a range of stakeholders at the state, district, and village-levels (Figure 2). 


\section{Figure 2--Organizational structure of SEWA's water campaign}

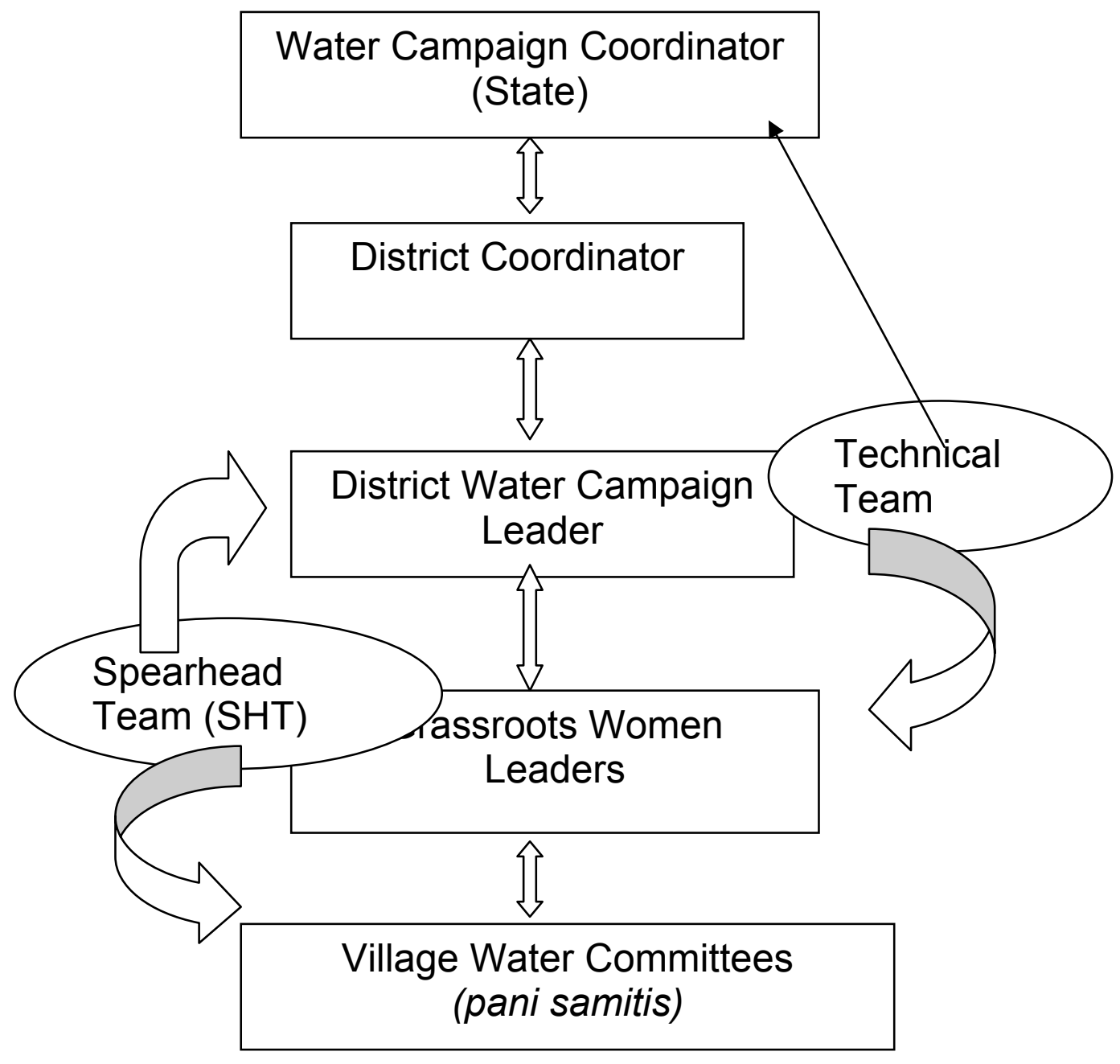

There is a Spearhead Team (SHT) in each district that supports the water campaign. Each SHT is head by a grassroots woman leader who receives guidance from the Water Campaign Coordinator. The SHTs comprise SEWA grassroots women leaders (who are paid a small honorarium) known as ageyvans of different pani samitis and a few SEWA organizers (total number 7-10). The SHTs are also affiliated with SEWA's district level association which gives them visibility.

The SHT is responsible for identifying local water problems, mobilizing village women through meetings and group discussions, and organizing user-based committees to manage water 
resources. At the village level, entry is through the village head (sarpanch) who calls for a gram sabha, a meeting of the entire village community. The village water committee or the pani samiti is elected in the gram sabha. The majority of the members are women, although in some villages supportive and proactive men are also nominated to the committees. The number of members on the committee is dependent on the size of the village but is always an odd number for the purpose of voting and decision making. Each committee also has one Chairperson and one Secretary.

The water campaign team leader from each district reports to, and takes guidance from, the water coordinator stationed in Ahmedabad (SEWA main office). The water coordinator also interacts directly with the SHTs at the district level. At another level, she also links up with the SEWA general secretary and through her, to SEWA's executive committee and office bearers.

All SHT leaders and organizers meet once a week in Ahmedabad to coordinate activities, discuss local water problems and also exchange information. Monthly meetings are held at the state level for all district coordinators and SHTs to share experiences and problems and to collectively devise strategies in agreement with the Water Campaign Coordinator and other SEWA functionaries. There is a practice of preparing monthly reports by the water committees (some of which are also published in the local language in the SEWA newsletter).

A monthly meeting is also conducted in selected villages where the campaign has demonstrated successful water-related activities to discuss strategies that have the potential to contribute to the water campaign. Such meetings can enhance lateral learning among members, thus giving them an opportunity to share experiences of how to address a variety of water problems by women (Verhagen and Agarwal, 2004). Consequently, the entire process not only 
builds the capacities of grassroots women but also, has an empowering effect on them (Ahmed 2002).

The outputs and achievements of SEWA's development-cum-struggle mode in terms of on-the-ground campaign results are as follows:

1. Construction of roof rainwater harvesting structures

2. Construction of plastic-lined ponds

3. Operation and maintenance of a Rural Piped Water Supply Scheme

4. Repair and maintenance of handpumps

5. Revival of traditional sources of drinking water

6. Installation of pulley systems in surface wells

The outputs are guided by two underlying principles: governing by women and combining traditional knowledge and skills with modern technology. Three examples have been selected to highlight the actions at the grassroots level undertaken by women members of SEWA as part of the Water Campaign: up-gradation and revival of traditional sources of water; rainwater harvesting and; technical training of women members of SEWA for building and maintaining water infrastructure at the village level. They are described in Boxes 1-3. 


\section{Box 1--Revival and upgrading of traditional sources of $\mathbf{w}$-ater}

Traditional sources of water (wells and ponds) often face neglect with the establishment of the piped water supply to villages. Rejuvenating these sources pose two challenges to women. First, being community assets, traditional sources of water require a community-based approach, when short-term efforts at repair are not enough. There is also a need for a long-term commitment to maintain the pond or well and to distribute the benefits equally. Second, women being the main water users, are traditionally not involved in the management of local water sources and therefore there is a need to change power relations in favor of the poor rural women.

The Millennium Campaign, with the help of the pani samitis, organizes the execution of actual repair/up-gradation work, including financial matters. SEWA organizers and engineers provide the logistic and technical support. SEWA ensures that women play a leading role in the entire process of revival of the traditional water sources, and undertake tailor-made training and on-the-spot capacity building to become efficient water managers. For example, when ponds need to be repaired, the pond and feeding channels are de-silted, bunds are improved and an outlet is constructed. If needed, the ponds are lined with a plastic film to prevent salinity. Wells on the other hand are also de-silted, cleaned and a new boundary wall at the top with a concrete platform is constructed. They are also fitted with a pulley to make fetching water less strenuous. The community is expected to make a contribution of 10 percent of the costs, either in labor or cash. Sometimes SEWA creates employment through its water infrastructure construction works and deducts 10 percent of the wages as part of their contribution to community maintenance fund. Capacity building of women is also done through exposure visits to other areas where such activities have proved to be successful.

Upgraded and repaired community water sources have led to improvements in the quality of water and have also reduced the time spent in fetching water for all the women interviewed in the six villages. The water committee has imposed regulations in the usage of water (to maintain cleanliness and reduce wastage) from wells and ponds, thereby establishing a good governance system. Women could engage themselves in income-generating activities with the time saved from fetching water. Such a change also had an impact on gender/power relations both at the household and community levels and has also contributed towards greater gender equity in terms of women's decision making and participation in local water management.

The challenge for the government however, is to develop a more holistic and participative approach to the improvement of domestic water supply - for livestock, kitchen gardens and income generation. Because of depleting ground water tables and salinity the revival of traditional sources is expensive, especially the plastic lining of ponds, and the government needs to take cognition of this problem. 


\section{Box 2--Roof rainwater harvesting}

Promotion of rainwater harvesting is a major initiative of SEWA's Women, Work and Water Campaign. In many areas of Gujarat, ground water is not accessible or not fit for human consumption. Through its water campaign, SEWA realized that rainwater harvesting is a viable alternative to transporting water over long distances by pipelines and/or tankers. Roof rainwater harvesting structures use a roof to catch the rain and store it in a tank. In the semi-arid areas, with an average annual rainfall of $300 \mathrm{~mm}$, a roofing area of $30 \mathrm{sq}$ meters provides a family with 90,000 liters of safe drinking water. This is enough to provide water to a family of five with 20 liters of water a day for three months. The construction cost is around US $\$ 300$ with negligible running costs. After a resolution is passed in the gram sabha on the agreement of households to share 10 percent of the construction costs in either cash or labor, the individual beneficiaries (also identified by SEWA) with the help of SEWA engineers, select a site, prepare a cost estimate, order construction materials and select a mason. Household members excavate the pit as part of their contribution. Women are trained to maintain the structures, including cleaning the tank with lime and flushing out the first rainwater collected.

In many villages there are few concrete roofs and SEWA along with the pani samiti decide to build community tanks using the roofs of community buildings such as schools, health centers, dairy society buildings etc. to harvest rainwater, with a capacity of 60,000 liters. The communities themselves have worked out a system of water sharing. In order to cater to the needs of all sections and avoid conflicts within the community, it is necessary to have more than one community tank in the village.

Rainwater harvesting has several advantages for women. It provides water at the doorstep, reducing the time women need to spend in collecting drinking water; it can be managed at the household level; it reduces the dependency on the other water supply systems controlled by men; it is a simple technology that women can learn by using locally available materials and; the tanks can used for storing water that is brought by the tanker in drought months of the year. 


\section{Box 3--SEWA's barefoot water technicians}

In many villages, handpumps are the sole source of drinking water. Handing over the maintenance of handpumps to grassroots women by the government is one of the initiatives of SEWA's Women, Work and Water Campaign to improve the access to safe drinking water. TheWater Board found it increasingly difficult to maintain 10,000 handpumps, while villagers found it cumbersome to report to the board on malfunctioning handpumps due to long-winding bureaucratic procedures. Women suffered in the process as they had to spend 6 hours a day in fetching water from long distances. The Water Board realized the need for involvement and collaboration of private players and NGOs in handpump maintenance. After an initial struggle with the water board, SEWA was able to convince the water bureaucrats that women could manage and maintain the handpumps. This was followed by regular training programs for women by the board. Women members for training were identified by SEWA with the help of the 'pani samiti'. More than 2500 women had been technically trained by 2004 . SEWA supports the trained women technicians with a small fee and vehicle expenses to travel to villages with their tools and spare parts for repairing handpumps. The task of overhauling a handpump requires six women technicians as there is a need to lift the pipe which is 150-200 feet long. They receive a fee from the water board for the work - overhauling and repairing of the handpumps. Initially, women faced problems as technical knowledge is considered a male domain and their work was not taken seriously by the villagers. Only after women proved themselves as able technicians were they accepted by the community.

With SEWA's intervention, handpumps are functioning efficiently. Villagers now register complaints for repair to the women's group trained by SEWA, and the time gap between complaints and repair has been reduced from 45 days to two to three days, on average. Women have also gained economically from the maintenance work - around Rs 5,000 annually which is an important supplement to the highly volatile incomes from agriculture. Equally important is their awareness of the importance of their role in the society.

In addition to handpumps, women have been trained in maintaining government pipelines operation and maintenance (digging pits, fitting pipelines, cement work and plugging the leakages etc.). This is the first time in India that such activities have been initiated with the help of SEWA women members. The success rate is high and the water board is very keen to continue with this collaboration.

Source: SEWA 2003

In all of the activities initiated by SEWA, the underlying strategy is to link environmental protection with livelihoods, whereas mainstream state agencies tend to deal with these two issues as mutually exclusive. For example, in Gujarat there are several instances of how the government is allowing extraction of ground water (at times as low as 600-900 feet) from the fringe villages to meet urban demand, with total disregard for the drying of aquifers and the loss of water for 
irrigation purpose. However, in the case of SEWA, it is observed that women are motivated to rebuild their environmental bases if they are convinced of tangible economic benefits in doing so.

\section{COLLECTIVE ACTION OF WOMEN - THE STRUGGLE AND SUCCESS}

This section discusses women's struggles in the Millennium Campaign in different parts of rural Gujarat. Collective action enables women to withstand societal, state and household pressures and conflicts and to move ahead in the campaign. At the start of the water campaign, women were reluctant to participate because water infrastructure development and its management were regarded as male territory. Most men were also non-cooperative. They were critical of women entering the public domain on this issue, and several went so far as to say they would not drink water from a source created by women. Many men threatened not to work on water harvesting structures that would be managed by women. Some men openly said that women would make financial blunders and force them to mortgage their lands (as all land titles are held in men's names) to repay their debts. Through the facilitation of SEWA's district level functionaries and agevans (women leaders) at the village level, gradually women members gained confidence and were able to participate in public meetings and also voice their concerns on water management. Such facilitation included regular contact with the women, meetings, capacity building, interfacing between the women's group and the water board and above all patience to persuade grassroots women to participate and own the water campaign. It should be borne in mind that SEWA had already been intervening in the villages for other development programs through women's groups and thus communities did not find it novel to interact with 
the functionaries in connection with the water program. Group solidarity among women played an important role in strengthening and sustaining the program. Furthermore, trained women demonstrated their capability of effectively repairing the handpumps without the support of men. Once the communities began to experience improved water supplies (i.e. handpumps and pipelines) and to accept women as technicians, the women could conduct themselves confidently in the public domain. The attitudes of men also began to change and they came forward to support the women in water infrastructure maintenance activities and also to encourage them to participate fully in the program. The fact that men did not hinder women's activities in the public domain also indicates their tacit support towards the program.

Within a year of the water campaign, women gained confidence to lead water activities in order to raise their productivity and income and improve their livelihoods. A year after the water activities were initiated, the promising results prompted more women to join the campaign. Poonamben of Bharvad village, Radhanpur, recounts how no one wanted to join the pani samities initially. "Now we've learned so much about measurements, maps, and surveying methods that everyone wants to become a member and know about these things."(Capoor 2003) SEWA's argument is that because women are primarily responsible for fetching and using water for domestic purposes, cattle, and kitchen gardens, it is necessary to give them prominent roles in water governance. Such a premise along with women's collective action made it easier for SEWA to continue with water-related activities.

Although the water campaign is spread over 500 villages involving 30,000 women, Table 1 gives a picture of the number of women mobilized in the year 2001. 
Table 1 - Number of women mobilized in water campaign (2001)

\begin{tabular}{lllll}
\hline S.No. & District & No. of villages & $\begin{array}{l}\text { No. of gram } \\
\text { sabhas organized }\end{array}$ & $\begin{array}{l}\text { No. of women } \\
\text { mobilized }\end{array}$ \\
\hline 1 & Vadodara & 17 & 85 & 8,500 \\
2 & Sabarkantha & 40 & 200 & 20,000 \\
3 & Surendranagar & 30 & 150 & 16,000 \\
4 & Kheda & 30 & 180 & 17,820 \\
5 & Banaskantha & 45 & 175 & 17,000 \\
6 & Kutch & 25 & 125 & 12,500 \\
7 & Ahmedabad & 20 & 100 & 10,000 \\
8 & Gandhinagar & 06 & 30 & 3,000 \\
9 & Mehesana & 15 & 07 & 7,500 \\
\hline & Total & $\mathbf{2 2 8}$ & $\mathbf{1 0 5 2}$ & $\mathbf{1 1 , 2 3 2 0}$ \\
\hline
\end{tabular}

Source: SEWA (2001)

\section{GRASSROOTS INSTITUTION}

Women's collective action is manifest in the grassroots women's institutions (pani samitis) that form the backbone of the water campaign. Mobilization of women through organizing gram sabhas and establishing grassroots institutions to carry out the campaign activities has proved effective in the villages where SEWA is active. Discipline on the part of women members is reflected in their contribution of cash (10 percent of the cost of water infrastructure on either an individual or community basis depending on the ownership) or labor and attendance at SEWA organized meetings on a regular basis. In situations where women are unable to pay due to poor economic conditions, SEWA tries to help them either by providing a loan or through Self Help Groups in the village. It is observed that women have never defaulted in their payments for construction of water related infrastructure. However, sustaining the pani samitis in terms of its effectiveness is a challenge for women in the face of a patriarchal society and gender-insensitive state.

\section{TECHNICAL CADRE}

The other supporting structure that emerged in the campaign is the 'technical cadre' comprising the formally trained women engineers and a grassroots cadre of 'barefoot technicians' who contribute to the maintenance of piped water supply and handpumps in different districts. The increasing number of women being trained indicates that women's 
groups with the support of SEWA were successful in challenging the stereotype that men only can obtain technical training. After a long struggle, SEWA members were able to obtain formal recognition by the state. Similarly, women are also trained in the areas of environmental protection, sanitation and maintenance of water quality for drinking purposes. Training-oftrainers are also conducted, who can then independently train women at the village level, thereby increasing the number of members in such a cadre and strengthening their collective. Trained women also use their skills to earn an income in addition to contributing to the campaign activities.

\section{TRANSCENDING SOCIAL BARRIERS}

For the rural women in semi-arid parts of Gujarat, water is a major problem that affects all regardless of caste, class and ethnicity. That the campaign members are not driven by these social considerations is reflected in all the campaign activities, particularly those which involve community water structures or watershed activities. There are several instances where men have opposed women's participation in the group meetings or activities organized by SEWA because they have to interact with women of different castes. However, the experiences of SEWA have shown that women have not paid heed to such differences. SEWA has also taken precaution in constructing several community structures (e.g. tanks for rainwater collection) in different parts of the village so as to cater to the needs of all caste groups. SEWA's presence in the villages for the past 20 years or more has changed the attitude of the community, particularly its women. Through various awareness and capacity building programs, SEWA has been successful at helping women realize that their problems, such as accessing safe drinking water, can be solved only if different sections of the community come together as a collective. It is this collective voice, not women's differences, which will be heard by the world (personal communication with 
Ms. Bharti Bhavsar, SEWA Water Campaign Coordinator 2005). The women's group is also accountable to SEWA for building a long term relationship and trust. Thus, if women allow caste distinctions and other social differences to fracture the collective, they will lose SEWA's support.

\section{DIALOGUING WITH THE STATE}

With the support of SEWA, women have collectively represented their cause to the state's multiple water authorities at the local, district and state levels. Such interactions with state bodies like the GWSSB have resulted in a partnership of maintaining pipe lines and handpumps in the villages. Although the state was not gender-responsive initially, the GWSSB finds it convenient to delegate the responsibility of maintenance to the SEWA women members, as they have demonstrated their potential in carrying out the tasks in a smooth manner. There have been no complaints from the village community whatsoever in this regard. It was observed during the field study by the author in June 2005 that the contract for pipeline maintenance in one area has expired and the procedure to renew it is cumbersome. However, women have not given up and are expecting to renew the contract for which they have been collectively fighting.

At times, interference by male members in local bodies like the panchayat (village council) has had a profound impact on women's confidence in terms of voicing their concerns in the gram sabha or functioning in the public domain, as the men often belong to the same lineage/clan as the women. It is far more difficult for women to protest against their male kin (due to various relationships including that of avoidance) than against outsiders. 


\section{IMPACT OF COLLECTIVE ACTION ON WOMEN}

Through collective action, women have been successful in breaking the stereotype that their role is confined only to the private domain. SEWA's efforts at mobilizing women for the water campaign have successfully demonstrated to the village community, as well as to GWSSB, that women are capable of undertaking tasks related to water management without the assistance of men. This is the first major impact of the water campaign, where women have developed confidence and have proven to be self reliant in managing public infrastructure. With the support of SEWA, the process of capacity building has proved to be directly beneficial to the success of the program. Women's leadership roles in the campaign have also helped them to participate in other public institutions such as the panchayat (local council), particularly in raising questions and objections and in making their points of view heard either directly or indirectly. Such a change was also observed in the gram sabha, another male territory where women formerly came to the village meetings but were passive observers and participants. However, the water campaign has empowered the women to the extent of not only making them visible in the public domain but also, of ensuring that they participate in public institutions as equals with men. Such a change has far-reaching effects on women's empowerment, including the next generation of women.

With the increase in the membership of SEWA due to the campaign, social capital at the community level has strengthened. SEWA is instrumental in building on women's collective strength not only for water management activities but also for other programs relating to health, education, income generation (crafts and other activities), insurance, as well as capacity building for various activities. There is a synergy among all the activities where collective action forms a 
crucial component. Furthermore, SEWA strongly believes in investing in the same group/set of women for different programs (as it minimizes the transaction costs), which has a long and lasting impact on both the women and the organization. Grassroots women no more hesitate to own up to tasks and responsibilities. In addition, the same set of functionaries at the community level is involved in various programs, so that their familiarity with the grassroots situation is an advantage to bring about a synergy in different activities.

The most significant impact of the water campaign has been on women's workloads in terms of time saved from fetching water, which women are now able to devote to productive work. Income generation has led to better financial security and quality of life. Table 2 gives an idea of the time profiles of women before and after the construction of the roof rainwater harvesting tanks.

Table 2 - Time Profiles (N=6 FGDs)

\begin{tabular}{llccccr}
\hline Activity & Before & After & $\begin{array}{c}\text { Monsoon } \\
\text { Difference }\end{array}$ & Before & After & $\begin{array}{r}\text { Summer } \\
\text { Difference }\end{array}$ \\
\hline $\begin{array}{l}\text { 1. Sleep } \\
\text { 2. Household } \\
\quad \text { Work }\end{array}$ & 7.0 & 7.6 & 0.6 & 6.8 & 7.4 & 0.6 \\
$\begin{array}{l}\text { 3. Fetching } \\
\quad \text { Water }\end{array}$ & 5.2 & 4.6 & -0.6 & 6.0 & 5.0 & -1.0 \\
$\begin{array}{l}\text { 4. Social } \\
\quad \text { Activities }\end{array}$ & 3.2 & 0.8 & -2.4 & 3.4 & 1.4 & -2.0 \\
$\begin{array}{l}\text { 5. Income } \\
\text { generation }\end{array}$ & 2.0 & 2.0 & 0.0 & 2.8 & 2.8 & 0.0 \\
Total & 6.6 & 9.0 & 2.4 & 5.0 & 7.4 & 2.4 \\
\hline Source SEWA 2003 & 24.0 & 24.0 & & 24.0 & 24.0 & \\
\hline
\end{tabular}

With the time saved from fetching water, women are able to earn an extra income, which is around Rs 17-20 per day. In addition, women are able to get adequate rest and perform more household work. 
The confidence of women to function in the public domain as a collective is clearly observed in the water campaign. Women are better able to deal with conflicts, especially at the community level, where it sometimes requires them to defy their husbands in meetings. Alcoholism, for example, is a problem in many villages where men spend a substantial portion of household income on locally brewed liquor. Where women have formed strong collectives and are active in the public domain, they have been able to fight against alcoholism by damaging local breweries and shaming their husbands in village council meetings. There are instances where alcoholism in some villages has dissipated or even been abolished (personal communication with SEWA Water Coordinator, Ahmedabad).

Collective action has also encouraged women to initiate activities on their own such as formation of Self Help Groups (SHGs) for savings and thrift with the support of SEWA. Thrift has helped women to build roof rainwater harvesting structures at the household level. In the SEWA meetings, women's groups strongly express concern about a lack of employment opportunities for their husbands, the education of the girl child and the marketing of their crafts, among the many problems they face in their lives. Such expressions of women are what SEWA believes is important for any substantive social change, including changes in gender relations in rural Gujarat. A visible impact of availability of water through women's efforts in the water campaign is reduction in migration of both women and men. This fact clearly emerged in eight of the 13 FGDs conducted in the villages. Prior to the water campaign, entire households used to migrate with their cattle to far away places in search of water and jobs. With water security, there has been a visible decline in out-migration of women and children. Some men do migrate nearby for jobs but not for long term. The scope of the paper does not allow for a more in-depth research 
in water security and migration trends. Figure 3 gives a graphic presentation of the impact of the water campaign on women.

Figure 3 - Impact of SEWA's water campaign (collective action) on women

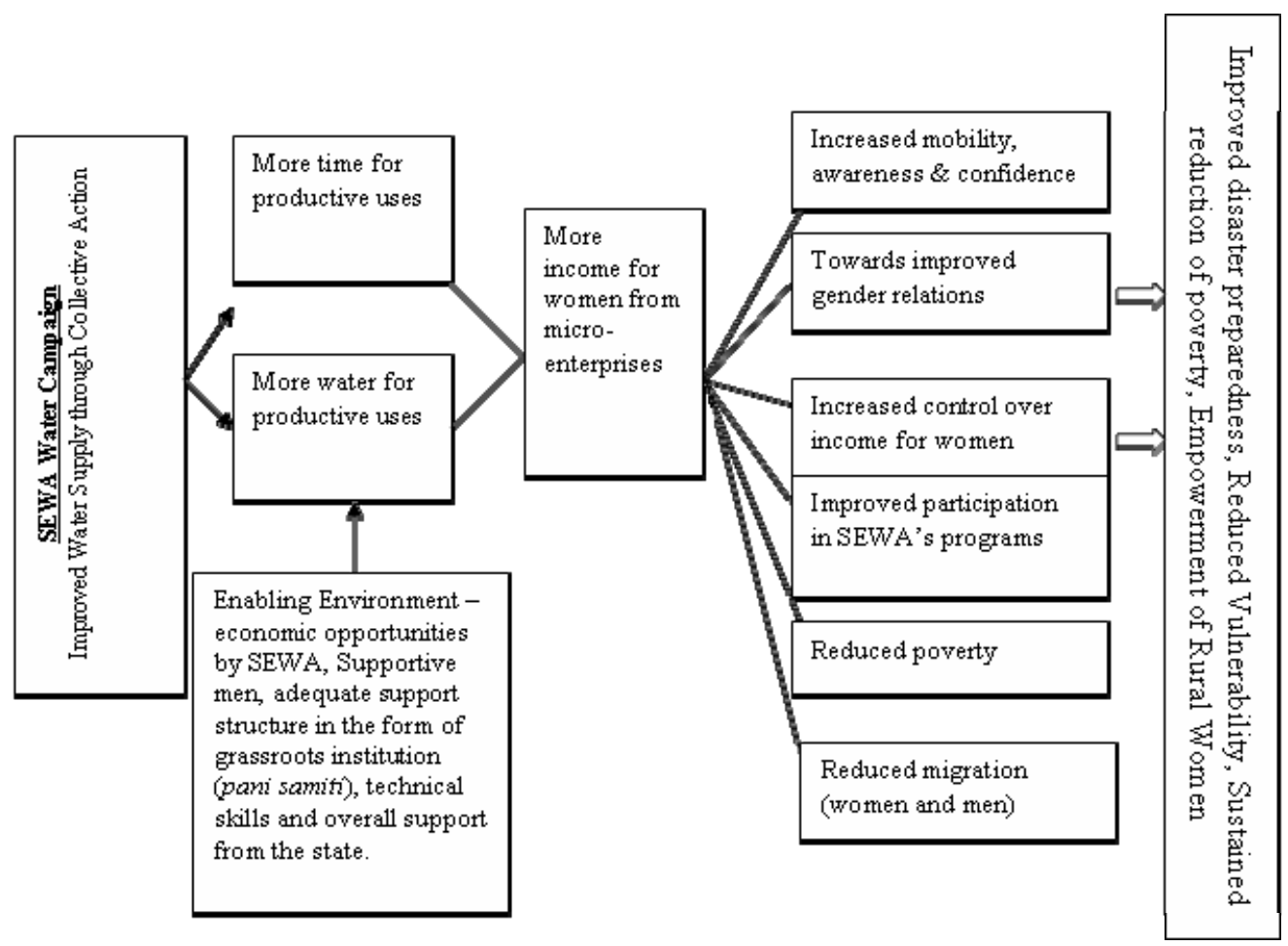

For any impact to be effective for rural women in the long run, it is essential to change gender relations. Unless there is a change towards a more egalitarian situation, any impact will be difficult to sustain. In a patriarchal set up, change in gender relations at the household level is an important indicator of collective action's ability to contribute to gender equity. While the scope of this study did not permit a detailed exploration of gender relations at the household level, it was observed that in some households, particularly those of some SEWA leaders, men have become more supportive of allowing women to spend time outside of the home and make decisions in accumulated savings, as well as educating the girl child. That women are able to come out of the confines of their home and participate in the water campaign activities is a big achievement for SEWA and is also a critical step towards women's empowerment. 


\section{CONCLUDING REMARKS}

The most significant impact of SEWA's Women, Water and Work Campaign has been the empowerment of women in terms of their capacity to undertake activities independently, or collectively, in the public domain. The success of the campaign can be clearly attributed to the institutional arrangements at the community level (pani samitis); the leadership initiatives which mobilized women at the village level; the role played by women's collectives in sustaining the activities of the campaign; the women's sense of ownership of local water resources and infrastructure; the democratic and transparent process of distribution of benefits among community members; and above all, the strong group cohesiveness among community women.

Women's collective agency has been enhanced by, and has also strengthened, the Women, Water and Work Campaign. In rural Gujarat, collective action is a strategy that women have successfully adopted to come together as a group, network and work with SEWA. As individuals, their voices are subdued and they are unable to make any significant impact at the community level. However, in the public domain, women are able to undertake activities relating to the campaign independently of men, thereby demonstrating an increased sense of ownership and confidence in water management.

The Women, Work and Water Campaign has shed light on certain significant principles that have the potential to guide interventions in the water sector. What clearly emerges is that through women's collective action (mobilization and formation of grassroots institutions), good governance for sustaining local water management and "engendering" of the state to some extent, is possible. Another aspect that cannot be overlooked is reduction in migration among both women and men due to increased availability of water for their livelihoods. However, the larger question remains as to whether the impact on gender relations that is observed at the 
collective level has percolated to the household level. Within the household, women tend to avoid conflicts and take on the burden of all domestic responsibilities so that they are not prevented by their husbands from going out to work for the water campaign. While an increase in income places women in an advantageous bargaining position within the household, visible changes in gender relations are yet to occur in the private sphere. Indeed, the observations in the field indicate that although gender-equitable change processes have begun at the household level they are yet to have a widespread impact.

Though SEWA functionaries are very positive about the changes in women's condition and position since the onset of the Women, Work and Water Campaign, much change remains to be made in order for women to achieve a footing equal to men. Collective action has the potential to change gender relations at the household level when women use their collective strength to take on issues like violence against women, son preference and neglect of the girl child (which is very rampant in rural Gujarat). Although this paper focuses on water management and women's role in the public domain through collective action, constraints within the household need to be critically examined and explored in order to understand changes in gender relations as a fundamental aspect for any collective action to take place beyond the household. 


\section{REFERENCES}

Agarwal, B. 2000. Conceptualising environmental collective action: why gender matters. Cambridge Journal of Economics 42(3): 283-310.

Ahmed, S. 2002. Mainstreaming gender equity in water management: institutions, policy and practice in Gujarat, India. In Natural Resources Management and Gender: A Global resource book, ed. Cummings S., H. van Dam, and M. Valk. London: Oxfam Publishing.

Ahmed, S. 2005. SEWA: Campaigning for water, women and work. In Flowing upstream: empowering women through water management initiatives in India, ed. Ahmed, S. Ahmedababad, India: Centre for Environment Education.

Baland, J.M., Platteau J.P. 1996. Halting degradation of natural resources: Is there a role for rural communities? Oxford, UK: Clarendon Press.

Capoor, A. 2003. Women, water and work: The success of the Self-Employed Women's Association. In World resources 2002-2004: Decisions for the earth: Balance, voice and power; Washington D.C.: United Nations Development Programme, World Bank, World Resources Institute.

Chen, M. 1993. Women and wasteland development in India: an issue paper. In Women and wasteland development in India, ed. Singh A. and N. Bura. New Delhi: Sage Publications.

D'Silva, E. and S. Pai. 2003. Social capital and collective action: development outcomes in forest protection and watershed development. Economic and Political Weekly 38(14): 1404-1415.

Meinzen-Dick, R, K.V. Raju, and A. Gulati. 2002. What affects organization and collective action for managing resources? evidence from canal irrigation systems in India. World Development 30(4): 649-666.

Mishra-Panda, S. 1996. Forest Degradation, Changing Livelihoods and Gender Relations: A Study of Two Tribal Communities in Orissa. Unpublished Doctoral Dissertation. Bangkok: Asian Institute of Technology.

Nanavathy, R. 2000. Women, water and work: SEWA's Millennium Campaign. In Water for food and rural development: Approaches and initiatives in South Asia, ed. Mollinga, P.P. New Delhi: Sage Publications.

Ostrom, E. 1990. Governing the Commons. Cambridge, UK: Cambridge University Press.

Poteete, A.R. and E. Ostrom. 2004. Role of institutions in forest management. Development and Change 35 (3): 435-461. 
Reddy, R.V. 2000. Sustaining watershed management: institutional approach. Economic and Political Weekly 35 (38): 3435-3444.

Sarin, M. 1999. Who gains, who loses? Gender and equity concerns in joint forest management. New Delhi: Society for Promotion of Wastelands Development.

Shiva, V. 1988. Staying alive: Women, ecology and development. London: Zed Books.

SEWA. 2001. SEWA'S millennium water campaign: Women water and work. Ahmedabad, India: SEWA.

SEWA. 2003. Women's struggle for water. Ahmedabad, India: SEWA.

Verhagen, J. and R. Agarwal. 2004. Sewa's Water Campaign. Paper presented in the South Asia Conference, Attaining the MDGs in India: The Role of Public Policy and Service Delivery, June 17-18, New Delhi. IESE and World Bank.

Wade, R. 1998. Village Republics: Economic Conditions for Collective Action in South India. Cambridge, UK: Cambridge University Press. 


\section{List of CAPRi Working Papers}

01 Property Rights, Collective Action and Technologies for Natural Resource Management: A Conceptual Framework, by Anna Knox, Ruth Meinzen-Dick, and Peter Hazell, October 1998.

02 Assessing the Relationships between Property Rights and Technology Adoption in Smallholder Agriculture: A Review of Issues and Empirical Methods, by Frank Place and Brent Swallow, April 2000.

03 Impact of Land Tenure and Socioeconomic Factors on Mountain Terrace Maintenance in Yemen, by A. Aw-Hassan, M. Alsanabani and A. Bamatraf, July 2000.

04 Land Tenurial Systems and the Adoption of a Mucuna Planted Fallow in the Derived Savannas of West Africa, by Victor M. Manyong and Victorin A. Houndékon, July 2000.

05 Collective Action in Space: Assessing How Collective Action Varies Across an African Landscape, by Brent M. Swallow, Justine Wangila, Woudyalew Mulatu, Onyango Okello, and Nancy McCarthy, July 2000.

06 Land Tenure and the Adoption of Agricultural Technology in Haiti, by Glenn R. Smucker, T. Anderson White, and Michael Bannister, October 2000.

07 Collective Action in Ant Control, by Helle Munk Ravnborg, Ana Milena de la Cruz, María Del Pilar Guerrero, and Olaf Westermann, October 2000.

08 CAPRi Technical Workshop on Watershed Management Institutions: A Summary Paper, by Anna Knox and Subodh Gupta, October 2000.

09 The Role of Tenure in the Management of Trees at the Community Level: Theoretical and Empirical Analyses from Uganda and Malawi, by Frank Place and Keijiro Otsuka November 2000.

10 Collective Action and the Intensification of Cattle-Feeding Techniques a Village Case Study in Kenya's Coast Province, by Kimberly Swallow, November 2000.

11 Collective Action, Property Rights, and Devolution of Natural Resource Management: Exchange of Knowledge and Implications for Policy, by Anna Knox and Ruth MeinzenDick, January 2001. 
12 Land Dispute Resolution in Mozambique: Evidence and Institutions of Agroforestry Technology Adoption, by John Unruh, January 2001.

13 Between Market Failure, Policy Failure, and "Community Failure": Property Rights, Crop-Livestock Conflicts and the Adoption of Sustainable Land Use Practices in the Dry Area of Sri Lanka, by Regina Birner and Hasantha Gunaweera, March 2001.

14 Land Inheritance and Schooling in Matrilineal Societies: Evidence from Sumatra, by Agnes Quisumbing and Keijuro Otsuka, May 2001.

15 Tribes, State, and Technology Adoption in Arid Land Management, Syria, by Rae, J, Arab, G., Nordblom, T., Jani, K., and Gintzburger, G., June 2001.

16 The Effects of Scales, Flows, and Filters on Property Rights and Collective Action in Watershed Management, by Brent M. Swallow, Dennis P. Garrity, and Meine van Noordwijk, July 2001.

17 Evaluating Watershed Management Projects, by John Kerr and Kimberly Chung, August 2001.

18 Rethinking Rehabilitation: Socio-Ecology of Tanks and Water Harvesting in Rajasthan, North-West India, by Tushaar Shah and K.V.Raju, September 2001.

19 User Participation in Watershed Management and Research, by Nancy Johnson, Helle Munk Ravnborg, Olaf Westermann, and Kirsten Probst, September 2001.

20 Collective Action for Water Harvesting Irrigation in the Lerman-Chapala Basin, Mexico, by Christopher A. Scott and Paul Silva-Ochoa, October 2001.

21 Land Redistribution, Tenure Insecurity, and Intensity of Production: A Study of Farm Households in Southern Ethiopia, by Stein Holden and Hailu Yohannes, October 2001.

22 Legal Pluralism and Dynamic Property Rights, by Ruth Meinzen-Dick and Rajendra Pradhan, January 2002.

23 International Conference on Policy and Institutional Options for the Management of Rangelands in Dry Areas, by Tidiane Ngaido, Nancy McCarthy, and Monica Di Gregorio, January 2002.

24 Climatic Variablity and Cooperation in Rangeland Management: A Case Study From Niger, by Nancy McCarthy and Jean-Paul Vanderlinden, September 2002. 
25 Assessing the Factors Underlying the Differences in Group Performance:

Methodological Issues and Empirical Findings from the Highlands of Central Kenya, by Frank Place, Gatarwa Kariuki, Justine Wangila, Patti Kristjanson, Adolf Makauki, and Jessica Ndubi, November 2002.

26 The Importance of Social Capital in Colombian Rural Agro-Enterprises, by Nancy Johnson, Ruth Suarez, and Mark Lundy, November 2002.

27 Cooperation, Collective Action and Natural Resources Management in Burkina Faso: A Methodological Note, by Nancy McCarthy, Céline Dutilly-Diané, and Boureima Drabo, December 2002.

28 Understanding, Measuring and Utilizing Social Capital: Clarifying Concepts and Presenting a Field Application from India, by Anirudh Krishna, January 2003.

29 In Pursuit Of Comparable Concepts and Data, about Collective Action, by Amy Poteete And Elinor Ostrom, March 2003.

30 Methods of Consensus Building for Community Based Fisheries Management in Bangladesh and the Mekong Delta, by Parvin Sultana and Paul Thompson, May 2003.

31 Formal and Informal Systems in Support of Farmer Management of Agrobiodiversity: Some Policy Challenges to Consolidate Lessons Learned, by Marie Byström, March 2004.

32 What Do People Bring Into the Game: Experiments in the Field About Cooperation in the Commons, by Juan-Camilo Cárdenas and Elinor Ostrom, June 2004.

33 Methods for Studying Collective Action in Rural Development, by Ruth Meinzen-Dick, Monica Di Gregorio, and Nancy McCarthy, July 2004.

34 The Relationship between Collective Action and Intensification of Livestock Production: The Case of Northeastern Burkina Faso, by Nancy McCarthy, August 2004.

35 The Transformation of Property Rights in Kenya's Maasailand: Triggers and Motivations by Esther Mwangi, January 2005.

36 Farmers' Rights and Protection of Traditional Agricultural Knowledge, by Stephen B. Brush, January 2005.

37 Between Conservationism, Eco-Populism and Developmentalism - Discourses in Biodiversity Policy in Thailand and Indonesia, by Heidi Wittmer and Regina Birner, January 2005. 
38 Collective Action for the Conservation of On-Farm Genetic Diversity in a Center of Crop Diversity: An Assessment of the Role of Traditional Farmers' Networks, by Lone B. Badstue, Mauricio R. Bellon, Julien Berthaud, Alejandro Ramírez, Dagoberto Flores, Xóchitl Juárez, and Fabiola Ramírez, May 2005.

39 Institutional Innovations Towards Gender Equity in Agrobiodiversity Management: Collective Action in Kerala, South India,, by Martina Aruna Padmanabhan, June 2005.

40 The Voracious Appetites of Public versus Private Property: A View of Intellectual Property and Biodiversity from Legal Pluralism, by Melanie G. Wiber, July 2005.

41 Who Knows, Who Cares? Determinants of Enactment, Awareness and Compliance with Community Natural Resource Management Bylaws in Uganda, by Ephraim Nkonya, John Pender, Edward Kato, Samuel Mugarura, and James Muwonge, August 2005.

42 Localizing Demand and Supply of Environmental Services: Interactions with Property Rights, Collective Action and the Welfare of the Poor, by Brent Swallow, Ruth MeinzenDick, and Meine von Noordjwik, September 2005.

43 Initiatives for Rural Development through Collective Action: The Case of Household Participation in Group Activities in the Highlands of Central Kenya, By Gatarwa Kariuki and Frank Place, September 2005.

44 Are There Customary Rights to Plants? An Inquiry among the Baganda (Uganda), with Special Attention to Gender, by Patricia L. Howard and Gorettie Nabanoga, October 2005.

45 On Protecting Farmers' New Varieties: New Approaches to Rights on Collective Innovations in Plant Genetic Resources by Rene Salazar, Niels P. Louwaars, and Bert Visser, January 2006.

46 Subdividing the Commons: The Politics of Property Rights Transformation in Kenya's Maasailand, by Esther Mwangi, January 2006.

47 Biting the Bullet: How to Secure Access to Drylands Resources for Multiple Users, by Esther Mwangi and Stephan Dohrn, January 2006.

48 Property Rights and the Management of Animal Genetic Resources, by Simon Anderson and Roberta Centonze, February 2006.

49 From the Conservation of Genetic Diversity to the Promotion of Quality Foodstuff: Can the French Model of 'Appellation d'Origine Contrôlée' be Exported? by Valérie Boisvert, April 2006. 
50 Facilitating Collective Action and Enhancing Local Knowledge: A Herbal Medicine Case Study in Talaandig Communities, Philippines, by Herlina Hartanto and Cecil Valmores, April 2006.

51 Water, Women and Local Social Organization in the Western Kenya Highlands, by Elizabeth Were, Brent Swallow, and Jessica Roy, July 2006.

52 The Many Meanings of Collective Action: Lessons on Enhancing Gender Inclusion and Equity in Watershed Management, by Laura German, Hailemichael Taye, Sarah Charamila, Tesema Tolera, and Joseph Tanui, July 2006.

53 Decentralization and Environmental Conservation: Gender Effects from Participation in Joint Forest Management, by Arun Agrawal, Gautam Yadama, Raul Andrade, and Ajoy Bhattacharya, July 2006.

54 Improving the Effectiveness of Collective Action: Sharing Experiences from Community Forestry in Nepal, by Krishna P. Achyara and Popular Gentle, July 2006.

55 Groups, Networks, and Social Capital in the Philippine Communities, by Marie Godquin and Agnes R. Quisumbing, October 2006.

56 Collective Action in Plant Genetic Resources Management: Gendered Rules of Reputation, Trust and Reciprocity in Kerala, India, by Martina Aruna Padmanabhan, October 2006.

57 Gender and Local Floodplain Management Institutions--A case study from Bangladesh, by Parvin Sultana and Paul Thompson, October 2006.

58 Gender Differences in Mobilization for Collective Action: Case Studies of Villages in Northern Nigeria, by Saratu Abdulwahid, October 2006.

59 Gender, Social Capital and Information Exchange in Rural Uganda, by Enid Katungi, Svetlana Edmeades, and Melinda Smale, October 2006.

60 Rural Institutions and Producer Organizations in Imperfect Markets: Experiences from Producer Marketing Groups in Semi-Arid Eastern Kenya, by Bekele Shiferaw, Gideon Obare and Geoffrey Muricho, November 2006. 